\title{
Serum trace elements in insulin-dependent and non-insulin-dependent diabetes: a comparative study
}

This article was published in the following Dove Press journal: Diabetes, Metabolic Syndrome and Obesity:Targets and Therapy

\author{
Ahmed MAhmed' \\ Omar F Khabour ${ }^{1,2}$ \\ Akram H Awadalla ${ }^{3}$ \\ Hisham A Waggiallah ${ }^{4}$ \\ 'Department of Clinical Laboratory \\ Sciences, Faculty of Applied \\ Medical Sciences, Taibah University, \\ Medina, Saudi Arabia; ${ }^{2}$ Department \\ of Medical Laboratory Sciences, \\ Faculty of Applied Medical Sciences, \\ Jordan University of Science and \\ Technology, Irbid, Jordan; ${ }^{3}$ Department \\ of Clinical Chemistry, College \\ of Medical Laboratory Sciences, \\ Kordofan University, Alobayid, Sudan; \\ ${ }^{4}$ Department of Medical Laboratory \\ Sciences, Sattam Bin Abdulaziz \\ University, Alkharj, Saudi Arabia
}

Background: Diabetes mellitus is associated with imbalance in body trace elements. The aim of the current investigation was to compare the levels of trace elements ( $\mathrm{Zn}, \mathrm{Mg}, \mathrm{Mn}, \mathrm{Cu}, \mathrm{Na}, \mathrm{K}$, $\mathrm{Fe}, \mathrm{Ca}, \mathrm{Cr}$, and $\mathrm{Se}$ ) in insulin dependent (IDDM) and non-insulin dependent (NIDDM) diabetes. Methods: A total of 100 patients with diabetes (40 IDDM and 60 NIDDM) and 50 healthy subjects were recruited in the study from both genders. Biochemical measures include glucose, lipids, and $\mathrm{HbA1C}$.

Results: The results showed that $\mathrm{Zn}, \mathrm{Mg}, \mathrm{Cu}$ and $\mathrm{Cr}$ were significant lower in patients with diabetes compared to the control group $(P<0.01)$. In addition, $\mathrm{Zn}$ and $\mathrm{Cr}$ were significantly lower in IDDM than NIDDM $(P<0.05)$. Moreover, $\mathrm{Zn}$ and $\mathrm{Mg}$ levels were inversely correlated with HbA1c in IDDM and NIDDM $(P<0.05)$. Zn was inversely correlated with fasting blood glucose in IDDM $(P<0.05)$. Finally, no correlation between trace element levels with BMI was found $(P>0.05)$.

Conclusion: Disturbance in trace element profile among IDDM and NIDDM is similar. Keywords: trace elements, diabetes mellitus, IDDM, NIDDM

\section{Introduction}

Diabetes mellitus is a common metabolic disease that is characterized by misregulation of blood glucose levels leading to hyperglycemia. ${ }^{1,2}$ The disease affects millions of people worldwide and the number of people affected by diabetes is increasing. ${ }^{3}$

The prevalence of diabetes is high among Middle Eastern and North African countries with frequencies between $4 \%$ and $10 \% .{ }^{4,5}$ Diabetes is associated with several complications that include renal deteriorations, retinopathy leading to vision disturbance, nerve damage and predisposition to cardiovascular diseases. ${ }^{6,7}$ Diabetes can be divided into insulin-dependent (IDDM) and non-insulin-dependent diabetes (NIDDM). ${ }^{8}$ In the NIDDM, hyperglycemia arises from the loss of normal tissue sensitivity to insulin (also known as insulin resistance). ${ }^{9}$ In IDDM, hyperglycemia arises from insufficient production of insulin from pancreatic cells due to autoimmunity. ${ }^{10}$ The two types differ also in the management of the disease and its complications. ${ }^{11,12}$

Previous studies have shown alterations in the balance of trace elements in patients with diabetes. ${ }^{13,14}$ Trace elements play important roles in body metabolism and cellular homeostasis. ${ }^{15}$ This includes production, secretion and insulin activity pathway. ${ }^{16-18}$ For example, insulin mechanism of action has been shown to be modulated by $\mathrm{Mg}, \mathrm{Cr}, \mathrm{Zn}$, Mn, Se and others. ${ }^{16-18}$ Since IDDM and NIDDM differ in their etiology and management, we hypothesized that the balance of trace elements might differ between the two types. In support of this hypothesis, a previous study from Sudan showed significant
Correspondence: Ahmed M Ahmed Department of Clinical Laboratory Sciences, Faculty of Applied Medical Sciences, Taibah University, Medina, Saudi Arabia

Email ammohammed@taibahu.edu.sa 
difference in the levels of $\mathrm{Cr}$ between IDDM and NIDDM. ${ }^{19}$ Therefore, in the current study, impairment of trace elements among IDDM and NIDDM patients was examined. In addition, levels of trace elements in the two groups were correlated with glycemic control and lipid profile parameters.

\section{Methods}

\section{Participants}

A hundred patients with diabetes (40 IDDM and 60 NIDDM) (61 male, 39 female) were recruited from Jabir Abu Aliz Diabetes Center (Khartoum, Sudan). For comparison, 50 healthy subjects ( 30 male and 20 females) were included as controls. Inclusion criteria for diabetes group were: $\mathrm{HbA} 1 \mathrm{C}$ above $6.5 \%$, random blood glucose $\geq 11 \mathrm{mmol} / \mathrm{L}$, fasting blood glucose $(\mathrm{FBG}) \geq 7.7 \mathrm{mmol} / \mathrm{L}$. The threshold of FBG was selected slightly above guidelines for defining diabetes (ie, $7 \mathrm{mmol} / \mathrm{L}$ ) to exclude borderline patients. Exclusion criteria include patients with renal complications or failure, acute kidney infection, chronic illness other than diabetes that include liver disease, anemia, and thyroid disease, and vitamin/mineral supplements. ${ }^{19-21}$ The study was approved by Khartoum State Ministry of Health Research Ethics Committee, Khartoum, Sudan and by Research Ethics Committee of Applied Medical Sciences at Taibah University, Madinah, Saudi Arabia. Both committees utilized the ethical standards as laid down in the 1964 Declaration of Helsinki and its later amendments. Written informed consent was taken from participants after a full description of study objectives and procedures.

\section{Anthropometric parameters}

Body mass index (BMI) and waist circumference were measured as previously described. ${ }^{22}$ Classifications of BMI were: normal $\left(18.5-24.9 \mathrm{~kg} / \mathrm{m}^{2}\right)$, overweight $\left(25-29.9 \mathrm{~kg} / \mathrm{m}^{2}\right)$, and obese $\left(\geq 30.0 \mathrm{~kg} / \mathrm{m}^{2}\right)$.

\section{Biochemical parameters}

Fasting blood samples (about $3 \mathrm{~mL}$ each) were collected from participants in plain tubes using disposable syringes. All blood samples were allowed to clot at room temperature for 30 minutes and then centrifuged at $4,000 \times g$ to obtain the serum. Total cholesterol, triglyceride, HDL, and LDL were measured using a Hitachi autoanalyzer 704 (HoffmanLa Roche Ltd., Basel, Switzerland). Trace elements (Zn, $\mathrm{Mg}, \mathrm{Mn}, \mathrm{Cu}, \mathrm{Fe}, \mathrm{Ca}, \mathrm{Cr}$ and $\mathrm{Se}$ ) were determined using WFX-320 Atomic Absorption Spectrophotometer (Beijing Rayleigh Analytical Instrument Corporation (BRAIC), Beijing, China). ${ }^{23} \mathrm{Na}$ and $\mathrm{K}$ were determined using a flame photometer (JENWAY, model PFP7, Stone, UK). ${ }^{24}$

\section{Statistical analysis}

The data were analyzed using SPSS version 19 (IBM Corporation, Armonk, NY, USA). Comparisons that include three groups or more were conducted using ANOVA followed by Tukey post hoc test. Student's $t$-test and Pearson correlation were used for data that involved two groups. F comparisons that involve frequencies were performed using chi-squared/Fisher's exact test. A $P<0.05$ was used to indicate significant differences.

\section{Results}

Table 1 shows demographics of participants. The mean age of

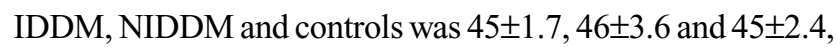
respectively $(P>0.05)$. In addition, gender ratios were not different between the three groups (Table 1, $P>0.05$ ). With respect to $\mathrm{BMI}$ and waist circumference, they were slightly higher in NIDDM than other groups $(P<0.05)$. In addition,

Table I Demographics of participants

\begin{tabular}{|c|c|c|c|c|}
\hline Characteristics & $\begin{array}{l}\text { IDDM } \\
n=40\end{array}$ & $\begin{array}{l}\text { NIDDM } \\
\mathrm{n}=60\end{array}$ & $\begin{array}{l}\text { Control } \\
n=50\end{array}$ & $P$-value \\
\hline Age, years & $45 \pm 1.7$ & $46 \pm 3.6$ & $45 \pm 2.4$ & $0.11^{\mathrm{a}}$ \\
\hline Gender (male, female) & $(27,13)$ & $(34,26)$ & $(30,20)$ & \\
\hline $\mathrm{BMI}, \mathrm{kg} / \mathrm{cm}^{2}$ & $23 \pm 3.3$ & $27 \pm 4.7^{*}$ & $23 \pm 2.4$ & $<0.00 I^{a}$ \\
\hline Normal, 18.5-24.9 (\%) & $37(92.5)$ & $20(33.3)$ & $43(86)$ & \\
\hline Overweight, 25-29.5 (\%) & $3(7.5)$ & $33(55.0)$ & $7(14)$ & $<0.00 I^{\mathrm{b}}$ \\
\hline Obese, >30 (\%) & $0(0)$ & $7(11.7)$ & $0(0)$ & \\
\hline Waist circumference, $\mathrm{cm}$ & $80.6 \pm 24.9$ & $86.1 \pm 24.2$ & $81.1 \pm 22.4$ & $0.42^{\mathrm{a}}$ \\
\hline$\leq 90(\%)$ & $38(95)$ & $22(36.7)$ & $45(90)$ & \\
\hline$>90(\%)$ & $2(5)$ & $38(63.3)$ & $5(10)$ & $<0.01^{b}$ \\
\hline Period of diabetes, years & $23.5 \pm 7.1^{*}$ & $5.8 \pm 1.8$ & - & $<0.001^{\mathrm{c}}$ \\
\hline
\end{tabular}

Notes: ${ }^{*} P<0.001$. 'ANOVA $P$-value; ${ }^{\text {a }}$ Fisher's exact $P$-value; ' $t$-test value.

Abbreviations: BMI, body mass index; IDDM, insulin-dependent diabetes mellitus; NIDDM, non-insulin-dependent diabetes mellitus. 
the frequency of obese patients and those with a waist circumference above $90 \mathrm{~cm}$ was higher in NIDDM compared to other groups $(P<0.01$, Table 1$)$.

Table 2 shows biochemical parameters between different groups. FBG, HbA1c, total cholesterol, triglyceride, LDL and HDL were significantly higher in patients with diabetes (IDDM and NIDDM) compared to the control group $(P<0.05)$ and the majority are within normal ranges (as shown by frequency data, Table 2) suggesting that the patients included in this study have a relatively good lifestyle and dietary habits.

With respect to trace elements, $\mathrm{Zn}, \mathrm{Mg}, \mathrm{Cu}$ and $\mathrm{Cr}$ were significantly lower in patients with diabetes compared to the control group $(P<0.05$, Table 3$)$. In addition, $\mathrm{Zn}$ and $\mathrm{Cr}$ were significantly lower in IDDM than NIDDM $(P<0.05)$.

The level of serum trace elements was compared in patients with diabetes according to different demographic and clinical parameters. When gender was considered $\mathrm{Zn}$ levels were higher in females compared to males $(P<0.05)$, whereas $\mathrm{Fe}$ and $\mathrm{Ca}$ were significantly higher in males compared to females $(P<0.01)$. Sodium was higher in normotensive compared to hypertensive patients $(P<0.01)$. However, no significant differences were detected with respect to trace elements among patients with diabetes when BMI was considered $(P>0.05)$.

Table 2 Fasting glucose, glycemic control and lipid profiles of participants

\begin{tabular}{|c|c|c|c|c|}
\hline Parameters & $\begin{array}{l}\text { IDDM } \\
\mathrm{n}=\mathbf{4 0}\end{array}$ & $\begin{array}{l}\text { NIDDM } \\
\mathrm{n}=60\end{array}$ & $\begin{array}{l}\text { Control } \\
n=50\end{array}$ & $P$-value \\
\hline $\mathrm{FBG}, \mathrm{mmol} / \mathrm{L}$ & $9.1 \pm 2.6^{*}$ & $8.8 \pm 1.7^{*}$ & $4.7 \pm 1.3$ & $>0.00 \mathrm{I}^{\mathrm{a}}$ \\
\hline $\mathrm{HbAlc} \%$ & $8.3 \pm 3.1 *$ & $8.1 \pm 3.7^{*}$ & $5.1 \pm 1.1$ & $>0.00 I^{a}$ \\
\hline$\leq 6 \%, \mathrm{n}(\%)$ & $18(45)$ & $31(51.7)$ & $50(100)$ & $0.42^{\mathrm{b}}$ \\
\hline$>6 \%, \mathrm{n}(\%)$ & $22(55)$ & $29(48.3)$ & $0(0)$ & \\
\hline Total cholesterol (mmol/L) & $4.3 \pm 1.1 *$ & $4 . I \pm 2.3^{*}$ & $3.2 \pm 0.7$ & $0.002^{\mathrm{a}}$ \\
\hline$\leq 6.2 \mathrm{mmol} / \mathrm{L}, \mathrm{n}(\%)$ & $27(67.5)$ & $45(75)$ & $48(96)$ & $0.0016^{b}$ \\
\hline$>6.2 \mathrm{mmol} / \mathrm{L}, \mathrm{n}(\%)$ & $13(32.5)$ & $15(25)$ & $2(4)$ & \\
\hline Triglyceride (mmol/L) & $1.5 \pm 0.4^{*}$ & $1.6 \pm 0.6 *$ & $1.0 \pm 0.3$ & $>0.00 I^{\mathrm{a}}$ \\
\hline$\leq 2.2 \mathrm{mmol} / \mathrm{L}, \mathrm{n}(\%)$ & $29(72.5)$ & $47(78.3)$ & $49(98)$ & $0.002^{b}$ \\
\hline$>2.2 \mathrm{mmol} / \mathrm{L}, \mathrm{n}(\%)$ & II (27.5) & $13(21.7)$ & $I(2)$ & \\
\hline $\mathrm{LDL}(\mathrm{mmol} / \mathrm{L})$ & $2.9 \pm 0.4^{*}$ & $3 . I \pm 0.7^{*}$ & $1.8 \pm 0.2$ & $>0.00 \mathrm{I}^{\mathrm{a}}$ \\
\hline$\leq 4.1 \mathrm{mmol} / \mathrm{L}, \mathrm{n}(\%)$ & $26(65)$ & $38(63.3)$ & $47(94)$ & $0.0004^{b}$ \\
\hline$>4.1 \mathrm{mmol} / \mathrm{L}, \mathrm{n}(\%)$ & $14(35)$ & $22(36.7)$ & $3(6)$ & \\
\hline $\mathrm{HDL}(\mathrm{mmol} / \mathrm{L})$ & $1.5 \pm 0.5^{*}$ & $1.5 \pm 0.2 *$ & $2.6 \pm 0.2$ & $>0.00 I^{a}$ \\
\hline$>1.0 \mathrm{mmol} / \mathrm{L}, \mathrm{n}(\%)$ & $29(72.5)$ & $4 \mathrm{I}(68.3)$ & $45(90)$ & $0.02^{\mathrm{b}}$ \\
\hline$\leq \mathrm{l} .0 \mathrm{mmol} / \mathrm{L}, \mathrm{n}(\%)$ & II (27.5) & $19(31.7)$ & $5(10)$ & \\
\hline
\end{tabular}

Notes: $* P<0.05$. aNOVA $P$-value; ${ }^{\circ}$ Fisher's exact/chi-squared test $P$-value.

Abbreviations: FBG, fasting blood glucose; IDDM, insulin-dependent diabetes mellitus; HDL, high-density lipoprotein; LDL, low-density lipoprotein; NIDDM, non-insulindependent diabetes mellitus.

Table 3 Levels of serum trace elements

\begin{tabular}{|c|c|c|c|}
\hline Characteristics & $\begin{array}{l}\text { IDDM } \\
n=40\end{array}$ & $\begin{array}{l}\text { NIDDM } \\
\mathrm{n}=60\end{array}$ & $\begin{array}{l}\text { Control } \\
n=50\end{array}$ \\
\hline Zinc (Zn), $\mu \mathrm{mol} / \mathrm{L}$ & $10 \pm 1.8^{*}$ & $12 \pm 1.7^{\mathrm{a}}$ & $16.1 \pm 2.3$ \\
\hline Magnesium (Mg), mmol/L & $0.72 \pm 0.2^{\mathrm{a}}$ & $0.72 \pm 0.4^{\mathrm{a}}$ & $0.91 \pm 0.2$ \\
\hline Manganese $(\mathrm{Mn}), \mu \mathrm{g} / \mathrm{L}$ & $0.25 \pm 0.2$ & $0.25 \pm 0.2$ & $0.26 \pm 0.1$ \\
\hline Copper (Cu), $\mu g / d L$ & $140.7 \pm 16.7^{\mathrm{a}}$ & $|4| .| \pm 2| .3^{a}$ & $152.3 \pm 17.4$ \\
\hline Sodium ( $\mathrm{Na}$ ), $\mathrm{mmol} / \mathrm{L}$ & $141.3 \pm 22.5$ & $139.4 \pm 16.9$ & $|40.1 \pm| 8.4$ \\
\hline Potassium (K), mmol/L & $3.4 \pm 2.5$ & $3.9 \pm 1.2$ & $4.1 \pm 0.6$ \\
\hline Iron $(\mathrm{Fe}), \mu \mathrm{mol} / \mathrm{L}$ & $22.6 \pm 6.4$ & $23.3 \pm 6.1$ & $24.6 \pm 5.8$ \\
\hline Calcium (Ca), mmol/L & $2.31 \pm 0.4$ & $2.36 \pm 0.2$ & $2.4 \pm 0.5$ \\
\hline Chromium (Cr), $\mu g / L$ & $1.4 \pm \mathrm{I} . \mathrm{I}^{*}$ & $1.9 \pm 1.2^{\mathrm{a}}$ & $2.5 \pm 0.9$ \\
\hline Selenium (Se), $\mu g / L$ & $134 \pm 13.5$ & $134 \pm 14.6$ & $138 \pm 10.4$ \\
\hline
\end{tabular}

Note: ${ }^{*} P<0.01 ;{ }^{\text {a }} P<0.05$

Abbreviations: IDDM, insulin-dependent diabetes mellitus; NIDDM, non-insulin-dependent diabetes mellitus. 
Table 4 shows correlations between the serum levels of trace elements and BMI, FBG, and HbAlc of the IDDM, NIDDM and control subjects. $\mathrm{Zn}$ and $\mathrm{Mg}$ levels were inversely correlated with HbA1c in IDDM and NIDDM $(P<0.05)$. Zn was inversely correlated with FBG in IDDM $(P<0.05)$.

\section{Discussion}

In the current study, modulation of trace elements ( $\mathrm{Zn}, \mathrm{Mg}$, $\mathrm{Mn}, \mathrm{Cu}, \mathrm{Na}, \mathrm{K}, \mathrm{Fe}, \mathrm{Ca}, \mathrm{Cr}$ and $\mathrm{Se}$ ) among IDDM and NIDDM patients was examined. The serum $\mathrm{Zn}, \mathrm{Mg}$ and $\mathrm{Cu}$ were found to be lower patients with diabetes than healthy controls.

Magnesium is an essential ion for all organisms and it is present in every cell in the human body. ${ }^{25}$ The role of $\mathrm{Mg}$ in glucose metabolism, transport and homeostasis is well documented. ${ }^{26,27}$ Several enzymes that involved in glucose metabolism require $\mathrm{Mg}$ ions for their activity. ${ }^{28}$ In addition, insulin has been shown to affect cellular Mg uptake. ${ }^{29}$ Alternatively, $\mathrm{Mg}$ plays a role in the release of insulin from pancreatic cells. ${ }^{30,31}$ Magnesium could also affect glucose homeostasis in an insulin independent pathway via modulation of membrane bound sodium, potassium ATPase activity, which is involved in cellular glucose transport. ${ }^{32,33}$ The results of the current investigation showed low levels of $\mathrm{Mg}$ in patients with diabetes, which was detected in both IDDM and NIDDM. In addition, $\mathrm{Mg}$ levels were negatively correlated with $\mathrm{HbA1c}$ in both diabetic subgroups. This highlights the importance of glycemic controls in maintaining ion balance inside the body. Disturbance of $\mathrm{Mg}$ levels in patients with diabetes agrees with previous reports that were conducted in other countries. ${ }^{16,34-36}$ Factors that might contribute to the low levels of $\mathrm{Mg}$ (also known as hypomagnesaemia) in diabetes include impairment of tubular reabsorption of $\mathrm{Mg}$ by the action of glycosuria and hyperglycemia. ${ }^{37}$ In addition, disturbance in insulin levels affects cellular $\mathrm{Mg}$ uptake. ${ }^{30,31}$ Since $\mathrm{Mg}$ is impaired in both IDDM and NIDDM and Mg levels were negatively correlated with $\mathrm{HbA1c}$, hyperglycemia seems to be the major factor that affects $\mathrm{Mg}$ levels in patients with diabetes.

Zinc is important for glucose homeostasis as it is involved the synthesis, storage and secretion of insulin, being a component of several metabolic enzymes, regulation of immunity and suppression of inflammation. ${ }^{38}$ Zinc also is important in normalization of the oxidative stress that plays a role in the $\beta$ cell destruction. ${ }^{39}$ Abnormal zinc metabolism is suggested to play a role in the etiology of diabetes and some of its complications. ${ }^{40}$ In the present study, serum zinc levels were found to be significantly lower in patients with diabetes, which was consistent with previous findings. ${ }^{41,42}$ Similar to $\mathrm{Mg}, \mathrm{Zn}$ was impaired in both IDDM and NIDDM. In addition, $\mathrm{Zn}$ levels were correlated with $\mathrm{HbA} 1 \mathrm{c}$. In a previous study, Zn was found to be deficient in the serum, leukocyte and hemoglobin of the IDDM subjects but not in NIDDM. ${ }^{43}$ In another study, plasma zinc was lower in both IDDM and NIDDM compared to healthy controls. ${ }^{44}$ Conversely, $\mathrm{Zn}$ was reported to be elevated in erythrocytes of children with IDDM. ${ }^{45}$ Thus, hyperglycemia seems to play a major role in the determination of $\mathrm{Zn}$ levels in patients with diabetes. ${ }^{46}$

Copper is an essential element that is important for energy production as it is a component of the mitochondrial cytochrome oxidative phosphorylation system. ${ }^{47}$ Therefore, $\mathrm{Cu}$ deficiency is expected to cause distortion of mitochondria, particularly in metabolically active cells as pancreatic and

Table 4 Correlations between the serum levels of trace elements and (BMI, FBG and HbAIc) of both diabetic groups and control healthy subjects

\begin{tabular}{|c|c|c|c|c|c|c|c|c|c|}
\hline \multirow[t]{2}{*}{ Elements } & \multicolumn{3}{|l|}{ IDDM } & \multicolumn{3}{|l|}{ NIDDM } & \multicolumn{3}{|l|}{ Control } \\
\hline & $\begin{array}{l}\text { BMI } \\
\mathrm{kg} / \mathrm{cm}^{2}\end{array}$ & $\begin{array}{l}\text { FBG } \\
\mathrm{mmol} / \mathrm{L}\end{array}$ & $\begin{array}{l}\text { HbAlc } \\
\%\end{array}$ & $\begin{array}{l}\text { BMI } \\
\mathrm{kg} / \mathrm{cm}^{2}\end{array}$ & $\begin{array}{l}\text { FBG } \\
\mathrm{mmol} / \mathrm{L}\end{array}$ & $\begin{array}{l}\text { HbAlc } \\
\%\end{array}$ & $\begin{array}{l}\text { BMI } \\
\mathrm{kg} / \mathrm{cm}^{2}\end{array}$ & $\begin{array}{l}\text { FBG } \\
\mathrm{mmol} / \mathrm{L}\end{array}$ & $\begin{array}{l}\text { HbAlc } \\
\%\end{array}$ \\
\hline $\mathrm{Zn}$ & -0.160 & $-0.4 I^{*}$ & $-0.36 *$ & -0.08 & -0.22 & $-0.39 *$ & -0.12 & -0.03 & -0.01 \\
\hline $\mathrm{Mg}$ & -0.17 & -0.19 & $-0.30 *$ & -0.03 & -0.08 & $-0.29 *$ & -0.04 & -0.01 & -0.01 \\
\hline$M n$ & -0.08 & -0.08 & -0.01 & -0.07 & -0.11 & -0.02 & -0.01 & 0.01 & 0.02 \\
\hline $\mathrm{Cu}$ & -0.02 & 0.09 & 0.02 & -0.05 & -0.07 & -0.11 & -0.01 & 0.02 & 0.03 \\
\hline $\mathrm{Na}$ & -0.01 & 0.04 & 0.03 & -0.01 & 0.06 & -0.04 & -0.02 & 0.03 & 0.07 \\
\hline K & 0.03 & 0.03 & 0.08 & 0.03 & 0.04 & 0.09 & 0.04 & 0.02 & 0.02 \\
\hline $\mathrm{Fe}$ & 0.01 & 0.02 & 0.04 & 0.01 & 0.01 & 0.02 & 0.01 & 0.06 & 0.03 \\
\hline $\mathrm{Ca}$ & -0.01 & 0.03 & 0.03 & -0.02 & 0.02 & 0.03 & -0.05 & 0.05 & 0.02 \\
\hline $\mathrm{Cr}$ & -0.06 & 0.18 & -0.03 & -17 & 0.03 & -0.02 & -0.01 & 0.01 & 0.04 \\
\hline $\mathrm{Se}$ & 0.03 & 0.01 & 0.03 & 0.05 & 0.04 & 0.02 & -0.12 & 0.02 & 0.06 \\
\hline
\end{tabular}

Note: $* P<0.05$.

Abbreviations: BMI, body mass index; FBG, fasting blood glucose; HbAlc, hemoglobin AIc; IDDM, insulin-dependent diabetes mellitus; NIDDM, non-insulin-dependent diabetes mellitus. 
liver cells. ${ }^{48}$ In the current study, $\mathrm{Cu}$ levels were found to be slightly decreased in IDDM and NIDDM patients with comparable magnitudes. Previous studies have reported conflicting results with respect to $\mathrm{Cu}$ levels in diabetes patients. ${ }^{49}$ For example, increase in plasma $\mathrm{Cu}$ levels was reported in studies from Taiwan, Brazil and Egypt ${ }^{47,50,51}$ whereas decrease or no change in $\mathrm{Cu}$ levels was reported in studies from the USA, ${ }^{52}$ Germany, ${ }^{53}$ Austria ${ }^{54}$ and Sudan (current study). The discrepancy could be due to differences in lifestyles and dietary habits between different populations.

The results found decreases in Cr levels in both IDDM and NIDDM patients. This is in agreement with most previous studies. ${ }^{16,55,56} \mathrm{Cr}$ is involved in insulin action and its chromium deficiency is related to glucose intolerance and insulin resistance in patients with diabetes. ${ }^{57}$ In addition, some studies have reported a lower risk of NIDDM in adults who were taking chromium-containing supplements. ${ }^{57}$ The results showed lower levels of Cr in IDDM than NIDDM. This suggests that insulin might play a role in $\mathrm{Cr}$ balance inside the body. However, one previous study from Germany has shown increases in $\mathrm{Cr}$ in plasma and polymorphonuclear cells of NIDDM. ${ }^{45}$ More studies are required to investigate the differences in $\mathrm{Cr}$ levels among different diabetic groups and in different populations.

\section{Limitations}

Among the study limitations is that some factors that might impact trace elements such as vitamin D levels, occupation and diabetes management medications were not evaluated in the sample. Taking into consideration such factors in future studies is recommended. In addition, the current findings need to be confirmed in a larger study from Sudan as the current sample size is relatively small. Moreover, evaluation of the status of trace elements in subjects with prediabetes and comparing that to diabetic groups is recommended in future investigations.

\section{Conclusion}

In Sudanese patients with diabetes, the metabolism of several trace elements was altered, namely, $\mathrm{Zn}, \mathrm{Mg}, \mathrm{Cu}$, and $\mathrm{Cr}$. The major finding was a decrease in the levels of $\mathrm{Zn}, \mathrm{Mg}, \mathrm{Cu}$ and $\mathrm{Cr}$. $\mathrm{Zn}$ and $\mathrm{Mg}$ were inversely correlated with $\mathrm{HbA1c}$ in all patients with diabetes. Zn was inversely correlated with FBG in NIDDM patients.

\section{Acknowledgment}

The authors should like to thank the Faculty of Applied Medical Sciences at Taibah University for its support.

\section{Disclosure}

The authors report no conflicts of interest in this work.

\section{References}

1. Galindo RJ, Fayfman M, Umpierrez GE. Perioperative management of hyperglycemia and diabetes in cardiac surgery patients. Endocrinol Metab Clin North Am. 2018;47(1):203-222.

2. Umpierrez GE, Bailey TS, Carcia D, Shaefer C, Shubrook JH, Skolnik $\mathrm{N}$. Improving postprandial hyperglycemia in patients with type 2 diabetes already on basal insulin therapy: Review of current strategies. $J$ Diabetes. 2018;10(2):94-111.

3. Han K, Yao J, Yin X, Zhao M, Sun Q. Review on the prevalence of diabetes and risk factors and situation of disease management in floating population in China. Glob Health Res Policy. 2017;2:33.

4. Alotaibi A, Perry L, Gholizadeh L, Al-Ganmi A. Incidence and prevalence rates of diabetes mellitus in Saudi Arabia: An overview. $J$ Epidemiol Glob Health. 2017;7(4):211-218.

5. Sherif S, Sumpio BE. Economic development and diabetes prevalence in MENA countries: Egypt and Saudi Arabia comparison. World $J$ Diabetes. 2015;6(2):304-311.

6. Ma RCW. Epidemiology of diabetes and diabetic complications in China. Diabetologia. 2018;61(6):1249-1260.

7. Shi GJ, Shi GR, Zhou JY, et al. Involvement of growth factors in diabetes mellitus and its complications: A general review. Biomed Pharmacother. 2018;101:510-527.

8. Slattery D, Amiel SA, Choudhary P. Optimal prandial timing of bolus insulin in diabetes management: a review. Diabet Med. 2018;35(3):306-316.

9. Bełtowski J, Wójcicka G, Jamroz-Wiśniewska A. Hydrogen sulfide in the regulation of insulin secretion and insulin sensitivity: Implications for the pathogenesis and treatment of diabetes mellitus. Biochem Pharmacol. 2018;149:60-76.

10. Nørgaard K, Sukumar N, Rafnsson SB, Saravanan P. Efficacy and safety of rapid-acting insulin analogs in special populations with type 1 diabetes or gestational diabetes: Systematic review and meta-analysis. Diabetes Ther. 2018;9(3):891-917.

11. Iqbal A, Novodvorsky P, Heller SR. Recent updates on type 1 diabetes mellitus management for clinicians. Diabetes Metab J. 2018;42(1):3-18.

12. Wang DD, $\mathrm{Hu} \mathrm{FB}, \mathrm{Fb} \mathrm{H}$. Precision nutrition for prevention and management of type 2 diabetes. Lancet Diabetes Endocrinol. 2018;6(5):416-426.

13. Siddiqui K, Bawazeer N, Joy SS. Variation in macro and trace elements in progression of type 2 diabetes. Sci World J. 2014;2014:461591.

14. Wolide AD, Zawdie B, Alemayehu T, Tadesse S. Association of trace metal elements with lipid profiles in type 2 diabetes mellitus patients: a cross sectional study. BMC Endocr Disord. 2017;17(1):64.

15. Ferreira CR, Gahl WA. Disorders of metal metabolism. Transl Sci Rare Dis. 2017;2(3-4):101-139.

16. Lin CC, Huang YL, Chromium HYL. Chromium, zinc and magnesium status in type 1 diabetes. Curr Opin Clin Nutr Metab Care. 2015;18(6):588-592.

17. Sun W, Yang J, Wang W, et al. The beneficial effects of Zn on Aktmediated insulin and cell survival signaling pathways in diabetes. $J$ Trace Elem Med Biol. 2018;46:117-127.

18. Triggiani V, Resta F, Guastamacchia E, et al. Role of antioxidants, essential fatty acids, carnitine, vitamins, phytochemicals and trace elements in the treatment of diabetes mellitus and its chronic complications. Endocr Metab Immune Disord Drug Targets. 2006;6(1):77-93.

19. Adam KM, Ibrahim HA. Level of serum chromium in Sudanese type 1 and type 2 diabetes mellitus patients. Am J Biochem. 2015;5(4):4.

20. Ahmed HA, Elmanna MM, Mohammed NB. Assessment of plasma copper, zinc, and glycated hemoglobin among Sudanese patients with type 2 diabetes mellitus in Khartoum State. Scholars Bulletin. 2016;2(9):8.

21. Mohammed HM, Mohammed NB, Sadiq IM. Assessment of zinc, Lipid profile and HB A1c in Sudanese with Type ii diabetes mellitus in Khartoum State. Saudi J Med Pharm Sci. 2017;3(3):5. 
22. Alomari MA, Al-Sheyab NA, Khabour OF, Alzoubi KH. Brain-derived neutrophic factor in adolescents smoking waterpipe: The Irbid TRY. Int J Dev Neurosci. 2018;67:14-18.

23. Kiziler AR, Aydemir B, Guzel S, et al. Comparison of before and after varicocelectomy levels of trace elements, nitric oxide, asymmetric dimethylarginine and malondialdehyde in the seminal plasma and peripheral and spermatic veins. Biol Trace Elem Res. 2015;167(2):172-178.

24. Albert V, Subramanian A, Rangarajan K, Pandey RM. Agreement of two different laboratory methods used to measure electrolytes. $J$ Lab Physicians. 2011;3(2):104-109.

25. Wu J, Xun P, Tang Q, Cai W, He K. Circulating magnesium levels and incidence of coronary heart diseases, hypertension, and type 2 diabetes mellitus: a meta-analysis of prospective cohort studies. Nutr J. 2017;16(1):60.

26. Lin CC, Tsweng GJ, Lee CF, Chen BH, Huang YL. Magnesium, zinc, and chromium levels in children, adolescents, and young adults with type 1 diabetes. Clin Nutr. 2016;35(4):880-884.

27. Veronese N, Watutantrige-Fernando S, Luchini C, et al. Effect of magnesium supplementation on glucose metabolism in people with or at risk of diabetes: a systematic review and meta-analysis of double-blind randomized controlled trials. Eur J Clin Nutr. 2016;70(12):1354-1359.

28. Barbagallo M, Dominguez LJ. Magnesium and type 2 diabetes. World J Diabetes. 2015;6(10):1152-1157.

29. de Baaij JH. The art of magnesium transport. Magnes Res. 2015;28(3):85-91.

30. Matsunobu S, Terashima Y, Senshu T, Sano H, Itoh H. Insulin secretion and glucose uptake in hypomagnesemic sheep fed a low magnesium, high potassium diet. J Nutr Biochem. 1990;1(3):167-171.

31. Rodríguez-Morán M, Guerrero-Romero F. Insulin secretion is decreased in non-diabetic individuals with hypomagnesaemia. Diabetes Metab Res Rev. 2011;27(6):590-596.

32. Apell HJ, Hitzler T, Schreiber G. Modulation of the Na,K-ATPase by magnesium ions. Biochemistry. 2017;56(7):1005-1016.

33. Lin RJ. A magnesium-binding nucleotide, a remodeling ATPase, and a wonderful RNA world. RNA. 2015;21(4):680.

34. Chen S, Jin X, Liu J, et al. Association of plasma magnesium with prediabetes and type 2 diabetes mellitus in adults. Sci Rep. 2017;7(1):12763.

35. Odusan OO, Familoni OB, Odewabi AO, Idowu AO, Adekolade AS. Patterns and correlates of serum magnesium levels in subsets of type 2 diabetes mellitus patients in Nigeria. Indian $J$ Endocrinol Metab. 2017;21(3):439-442.

36. Pokharel DR, Khadka D, Sigdel M, et al. Association of serum magnesium level with poor glycemic control and renal functions in Nepalese patients with type 2 diabetes mellitus. Diabetes Metab Syndr. 2017;11(Suppl 1):S417-S423.

37. Djurhuus MS, Skøtt P, Vaag A, et al. Hyperglycaemia enhances renal magnesium excretion in type 1 diabetic patients. Scand J Clin Lab Invest. 2000;60(5):403-410.

38. Olechnowicz J, Tinkov A, Skalny A, Suliburska J. Zinc status is associated with inflammation, oxidative stress, lipid, and glucose metabolism. J Physiol Sci. 2018;68(1):19-31.

39. Kawasaki E, Abiru N, Eguchi K. Prevention of type 1 diabetes: from the view point of beta cell damage. Diabetes Res Clin Pract. 2004;66 (Suppl 1):S27-S32.
40. Eshak ES, Iso H, Maruyama K, Muraki I, Tamakoshi A. Associations between dietary intakes of iron, copper and zinc with risk of type 2 diabetes mellitus: A large population-based prospective cohort study. Clin Nutr. 2018;37(2):667-674.

41. Chausmer AB. Zinc, insulin and diabetes. J Am Coll Nutr. 1998;17(2):109-115.

42. Viktorínová A, Toserová E, Krizko M, Duracková Z. Altered metabolism of copper, zinc, and magnesium is associated with increased levels of glycated hemoglobin in patients with diabetes mellitus. Metabolism. 2009;58(10):1477-1482.

43. Raz I, Havivi E. Trace elements in blood cells of diabetic subjects. Diabetes Res. 1989;10(1):21-24.

44. Walter RM, Uriu-Hare JY, Olin KL, et al. Copper, zinc, manganese, and magnesium status and complications of diabetes mellitus. Diabetes Care. 1991;14(11):1050-1056.

45. Kruse-Jarres JD, Rükgauer M. Trace elements in diabetes mellitus. Peculiarities and clinical validity of determinations in blood cells. $J$ Trace Elem Med Biol. 2000;14(1):21-27.

46. Shi Z, Yuan B, Qi L, Dai Y, Zuo H, Zhou M. Zinc intake and the risk of hyperglycemia among Chinese adults: the prospective Jiangsu Nutrition Study (JIN). J Nutr Health Aging. 2010;14(4):332-335.

47. Lowe J, Taveira-da-Silva R, Hilário-Souza E. Dissecting copper homeostasis in diabetes mellitus. IUBMB Life. 2017;69(4):255-262.

48. Scheiber I, Dringen R, Mercer JF. Copper: effects of deficiency and overload. Met Ions Life Sci. 2013;13:359-387.

49. Qiu Q, Zhang F, Zhu W, Wu J, Liang M. Copper in diabetes mellitus: a meta-analysis and systematic review of plasma and serum studies. Biol Trace Elem Res. 2017;177(1):53-63.

50. Abou-Seif MA, Youssef AA. Evaluation of some biochemical changes in diabetic patients. Clin Chim Acta. 2004;346(2):161-170.

51. Chen MD, Lin PY, Tsou CT, Wang JJ, Lin WH. Selected metals status in patients with noninsulin-dependent diabetes mellitus. Biol Trace Elem Res. 1995;50(2):119-124.

52. Rohn RD, Pleban P, Jenkins LL. Magnesium, zinc and copper in plasma and blood cellular components in children with IDDM. Clin Chim Acta. 1993;215(1):21-28.

53. Leonhardt W, Hanefeld M, Müller G, et al. Impact of concentrations of glycated hemoglobin, $\alpha$-tocopherol, copper, and manganese on oxidation of low-density lipoproteins in patients with type I diabetes, type II diabetes and control subjects. Clinica Chimica Acta. 1996;254(2):173-186.

54. Ekmekcioglu C, Prohaska C, Pomazal K, Steffan I, Schernthaner G, Marktl W. Concentrations of seven trace elements in different hematological matrices in patients with type 2 diabetes as compared to healthy controls. Biol Trace Elem Res. 2001;79(3):205-219.

55. Chen $\mathrm{S}$, Jin $\mathrm{X}$, Shan Z, et al. Inverse association of plasma chromium levels with newly diagnosed type 2 diabetes: A case-control study. Nutrients. 2017;9(3):294.

56. Doddigarla Z, Parwez I, Ahmad J. Correlation of serum chromium, zinc, magnesium and SOD levels with HbA1c in type 2 diabetes: A cross sectional analysis. Diabetes Metab Syndr. 2016;10(1):S126-S129.

57. Wang ZQ, Cefalu WT. Current concepts about chromium supplementation in type 2 diabetes and insulin resistance. Curr Diab Rep. 2010;10(2):145-151.

Diabetes, Metabolic Syndrome and Obesity: Targets and Therapy

Publish your work in this journal

Diabetes, Metabolic Syndrome and Obesity: Targets and Therapy is an international, peer-reviewed open-access journal committed to the rapid publication of the latest laboratory and clinical findings in the fields of diabetes, metabolic syndrome and obesity research. Original research, review, case reports, hypothesis formation, expert
Dovepress

opinion and commentaries are all considered for publication. The manuscript management system is completely online and includes a very quick and fair peer-review system, which is all easy to use. Visit http://www.dovepress.com/testimonials.php to read real quotes from published authors. 